\title{
Models of Constitution Making with Reference to Nepal
}

\author{
Bimal Prasad Lamichhane, Advocate
}

\begin{abstract}
Constitution is commonly called as the foundation, framework, guideline, roadmap, charter, established rule or legal order of government. It is the supreme and fundamental law of the state because constitution gives legitimacy or validity to all laws and no laws surviving against the constitution. Law is valid only if it in conformity with the constitution. Constitution being the basic and organic law of land the process of its making is quite important. Constitution making is the act of creating and reforming the body of fundamental principles that govern a state. Constitution making is, therefore, a critical entry point for shaping the future of a country, the exercise of power and the social compact among citizens and between citizens and their state. There is no universal rule, formula, exact method or model for making a constitution. There are several models used in constitution making such as commission model, expert model, constituent assembly model, referendum model, draft committee model, gift model, colonial model, adherence model, peace negotiation model, national conference model, etc. The models of constitution making is selected according to geographical, social, cultural, religious, economic, historical, political and legal system of a concerned country. Hence, in this article the author clearly presents the clear perspectives of constitution, constitution making and the popular models and the procedures used in making constitution with reference to Nepalese experiences and instances.
\end{abstract}

Keywords: Constitution, models, process, participation, state.

\section{Introductory}

A constitution is a document which contains the rules for the operation of an organization. Generally, a constitution comprises 
a body of rules regulating the way in which an institution or organization operates. Here we are concentrating on the constitution of the state and when the term constitution is used in the context of the government of a state, a different analysis is required. 'Every state needs some kind of order, some system by which a reasonably orderly process of government may emerge. This order or constitution must lay down certain rules which define the organs of government and how they originate, their mutual relationships and the relationships between government and people over whom its authority is exercised. A constitution is therefore, the basic design of the structure and powers of the state and the rights and duties of its citizens. There can be no state without a constitution. Sometimes the constitution of a state is definitely formulated in a document or documents; sometimes it is found in an established body of rules, maxims, traditions and practices in accordance with which its government is organized and its powers are exercised' (Kapur, 1957: 320). Thus, constitution is a foundation, framework, charter and roadmap of government that it consists of laws, understandings and customs of superior importance, particularly those which determine the structure of government and the distribution of powers among its agencies.

In the broadest sense, a constitution can be defined as being a body of rules which regulates the system of government within a state. It establishes the bodies and institutions which form part of that system, it provides for the power which they are to exercise, to determine how they are to interact and coexist with one another and perhaps most important of all, it is concerned with the relationship between government and the individual (Sharma, 2003: 1). Constitution is a set of doctrines and practices that form the fundamental organizing principles of a political state. It may be written or partly written and 
uncodified. Its provisions usually specify how the government is to be organized, what rights it shall have, and what rights shall be retained by the people" (Encyclopedia Britannica, 2004: 40).

A constitution may be said to be a collection of principles according to which the powers of the government, the rights of the governed, and the relations between the two are adjusted (Strong, 1975:11). The constitution of a country may be regarded as the fundamental law of the land, pertaining to the institution of the state and government of that country. Constitution is the base of state political system. It determines where to vest the sovereign power of a nation. It declares the jurisdiction and role of executive, legislature and judiciary. It delineates the power and responsibilities of the various instrumentalities of the state and its population. It also embodies and even strives to conduct, a common national, political and constitutional identity for the people it covers (Singh, 2013: 1). Every constitution represents the norms, values, visions of the state and is based on the social, cultural, economic and political ethos, faiths and aspirations of the people.

A constitution is the fundamental and basic law and provides the authority under which ordinary law is made. A constitution relates to the structure of the government, the extent and distribution of its power and the modes and principles of its operation, preceding ordinary laws in the point of time and embracing the settled policy of the nation' (Sharma, 2003:1617). Constitution is the supreme and fundamental law of the of the state. It is the supreme law because the constitution gives legitimacy or validity to all laws and no laws surviving against the constitution. Law is valid only if it is in conformity with the constitution. All other laws are created, validated and legalized by the constitution. Constitution is also the fundamental law of 
the land. It is incorporated in the Constitution of Nepal 2072 B.S., which states that, "This constitution is the fundamental law of Nepal. Any law inconsistent with this constitution shall, to the extent of such inconsistency, be void" (Article 1 of the Constitution of Nepal, 2072 B.S.). This provision ensures that the Constitution of Nepal is the fundamental law of land and all sub-ordinate laws enacted by the legislature, derive its legitimacy from the constitution.

Constitution-making is the act of rule-making required for the state as a supreme law by which the state is governed and achieves its objectives. Making of new constitution signifies a fresh start, restructuring and determining the future of the state. Constitution making is the process of creating, drafting, designing and constructing a new constitution for the state. It includes both the act of creating and reforming the body of fundamental principles that govern a state. It is a range of processes to draft and adopt a new constitution. 'Constitution making is the drafting and bringing into effect of a constitution' (Garner, 2014: 378). 'Constitution-making includes both the process for making a new constitution or amending an existing constitution as well as the substantive decisions about the design, form and content of the new or amended constitution' (Constitution Making Process, 2019). Constitution making is a difficult task. Constitution making is to design or shape the future road map of the country through which public participation is possible. It is more than producing a document. It is to create new democratic culture. (Timalsena, 2064: 210). Constitution is made by using several methods. Constitution making is a technical task and must be done with great care. Constitutionmaking has thus become complex, involving a number of tasks and stages and the proliferation of actors and institutions. Basing on the above concept and discussion the author in this article 
presents a clear picture of models of constitution making as per the need and the nature of constitution including models used in Nepal for making constitution.

\section{Objective and Methodology}

The objective of this article is to clarify and analyze the models and the procedures to be followed in constitution making process with Nepalese experiences and instances. In this article the author has adopted qualitative, analytical and historical research methodology and content analysis as a tool of research. Constitution is used as primary sources of data. Other information and knowledge have been collected and utilized from secondary literature sources such as published research works, authorized books, journals, articles and relevant websites. After collecting the data and literatures they are descriptively analyzed and analytically explained.

\section{Discussion on Models of Constitution Making}

There is no universal rule, model or procedure for making a constitution. Constitution can be framed by using several methods as per the need and situation. The major models and procedures used in making the constitution are elaborated hereunder:

\section{Constitution Making by Commission}

Commission is a body of persons appointed with necessary powers to draft or prepare the constitution. It is a group of people entrusted by a government or other official body with authority to perform the role of constitution making. They would draft constitutions on behalf of the people, state, rulers, monarchs or other concerned authority of the state who gave them the responsibility to do that task. It is a taskforce which preforms the task of preparing the 
draft of constitution in the structural arrangement within a certain time limit. The constitution making commission may be composed of experts, independent persons or may be certain political representatives. It acts primarily as an expert and facilitator rather than people's representative. The constitution making commission is employed to prepare an initial draft constitution. The commission prepares the draft of the constitution according to the issues, agendas, directions, mandate and guidelines given by the concerned authority of the state.

In the process of preparing the draft of constitution, the commissions may take public opinion, mandate of political parties or sovereign and conducts panel discussion with experts regarding various matters of constitution. After preparing the draft of the constitution within definite time frame, the commission submits the draft of the constitution to the concerned authority of the state under which they are working. After that the concerned authority may declare as it is or with some modifications of the drafted constitution. The constitution made by the constitution making the commission is more theoretical and philosophical rather than political. It may not be politically descriptive. This model of constitution making is appropriate for making the constitution in a short term and specific situation, particularly if the state is under grave political crisis. In this model massive and direct participation of people in the constitution making process is not possible. It used to be said that this model should not suffer from political and other external pressures.

In Nepal, the Constitution of the Kingdom of Nepal 2015 B.S. was drafted under this commission model under the 
chairmanship of Bhagawati Prasad Singh and other members of the constitution drafting commission were Surya Prasad Upadhyaya, Ranadhir Subba, Ram Raj Panta, Hora Prasad Joshi (Member Secretory) which was established by the (then) His Majesty King Mahendra (Regmi Part-II, 2061: 1158-1159). British constitutional expert, Sir Ivor Jennings was an advisor and consultant of this commission. 'Similarly, the Constitution of 2019 B.S. was also drafted by the Constitution Draft Commission (Sambidhan Masauda Aayog) under the chairmanship of Rishi Kesh Shah and other members of this commission were, Attorney General Sambhu Prasad Gyawali, Prakash Bahadur Khatri Chhetri (Chief Judge of the Court of Income and Tax), Mrs. Angur Baba Joshi, Dambar Narayan Yadhav and Secretary Kul Shekhar Sharma' (Regmi Part-II, 2061: 1255. Likewise, The Constitution of Kingdom of Nepal 2047 B.S. was also drafted by the commission named "Sambidhan Sujhav Aayog" which was under the chairmanship of Honorable Chief Justice Bishownath Upadhyaya and other members of this commission were Pradhumna Rajbhandari, Senior Advocate, Ramananda Prasad Singh, Advocate Mukunda Regmi, Advocate Daman Nath Dhungana, Nirmal Lama, Advocate Bharat Mohan Adhikari and Madhav Kumar Nepal (Leader CPNML).

\section{Expert Model}

Constitution can also be framed with the help of expert or the panel of experts. 'The participants of the constitution making process must have knowledge of what a constitution is and what its impact on the affairs of the state is. For this reason, trusted constitutional advisors and expert committees may contribute positively to the process' (Benomer, 2003: 
15). Experts like lawyers, often academic lawyers, legal and constitutional experts can play central role in making constitution. Both national and foreign experts may be used to make the constitution. In the modern time foreign experts have begun to play an important role in drafting and advising on constitutional issues. The experts would draft constitutions on behalf of the concerned authority of the state who gave them the responsibility to do that task. The concerned authority of the state provides the guidance, advice and instruction for drafting the constitution.

In such model selected experts or group of experts are hired and they prepare the constitutional draft as per the mandate of the state authority. Under this model, massive participation of people is not possible. In this model, the constitution however democratic may it be, is considered merely a contractual document. There is less chance of people's ownership in such a constitution but it does not simply mean that the constitution made by the experts cannot be long lasting. It is possible if the people to whom it is going to govern, accept it as a living document it can be an effective people's constitution. In this model too, people's representation can take part in the process of constitution making through dialogues, conversations and interactions with the committee and can put their interests before it. If the committee owes the duty of wider consultation with the stakeholders, the constitutional document can accommodate the different interest of the people and society (Singh, 2064: 59). Constitutional experts can be employed for consulting on various constitutional and legal issues and enrolled in several committees of drafting the constitution. 'The expert-making constitution or the constitution of traditional constitutionalism thinks of a constitution as a contract, 
negotiated by appropriate representatives, concluded, signed and observed' (Acharya, 2010: 277). The United States of America was the first originator of constitution making through the convention of experts. According to this model the Constitution of U.S.A. 1787 was made by a group of experts.

The constitutional and legal experts can also be used as the consultant for preparing the guideline or road map to frame the constitution. In context of Nepal, Government of Nepal Act, 2004 B.S. was also drafted with the help of the experts. Prime Minister Padma Shamsher requested the Indian Prime Minister Mr. Jawaharlal Nehru to send some constitutional experts from India for making the constitution of Nepal. Mr. Prakash Gupta (Law graduate from Cambridge University who was also a member of the Indian Constituent Assembly, Ragu Nath Singh (Member of Uttar Pradesh Legislative Assembly) and Ram Ugra Singh, Professor of Law at Lakhnow University were invited and involved to draft the first constitution of Nepal (Regmi Part-I, 2061: 7). After that the Constitution of 2015 B.S. was drafted by British constitutional expert Sir Ivor Jennings as a consultant and expert. Similarly, The Constitution of Nepal 2019 B.S. and The Constitution of Kingdom of Nepal 2047 B.S. was also drafted with the help of experts. In Nepal, 'soon after the election of the Constituent Assembly in 2008, the rules for constitution making and for parliamentary procedures had to be prepared. For this, a team of consultants was hired by the Asia Foundation at the request of the Constituent Assembly Secretariat to prepare the draft rules. The team consisted of Senior Advocate Purna Man Shakya, Dr. Bipin Adhikari and Dr. Bhimarjun Acharya. The team submitted the draft rules to the Constituent Assembly Secretariat within one month' 
(Shakya, 2014: 92).

\section{Constituent Assembly (C.A.) Model}

The word constituent assembly means meeting of a group of people living in a nation for the purpose of making constitution of their own country. According to Concise Law Dictionary, "Constituent assembly is a legislative body charged with the task of framing or revising a constitution" (Aiyar, 2009: 240). In this way, the literal meaning of the word 'constituent assembly' is a body of people's representatives formed with the objectives of forming a constitution which governs them. In a very technical term, constituent assembly can be defined as a body of elected or nominated representatives of people with the purpose of drafting and in some cases, adopting a new constitution.

Constitution-making through a popularly elected assembly could be seen as a kind of participatory process in itself because election campaigns provide the opportunity for people to engage in debates over constitutional issues and to vote for parties and candidates with the preferred constitutional agenda (Karki \& Edrisinha, 2014: 6). In constituent assembly model it is considered that, "the people are the author of the constitution. The constitution, to be a supreme law of the land, must be emanated from the supreme law-giver i.e. the people. 'Under this model of constitution making people's participation is regarded not only as a right of the people to make a constitution, but also a necessity as well. A claim of necessity for participation is based on the belief that without the general sense of ownership that comes from sharing authorship, the people will not respect and obey the constitution. That's the reason, it is required to maintain a conversation conducted by all stakeholders 
for the purpose of opening new entrants and issues and seeking a workable formula that will be sustainable in the near future. Open drafting committees aspiring to transparency in the decision making and approval of the people are immutable characteristics of this model. This model of constitution making reflects the general will of the people in the constitution' (Koirala, 2006: 34-35). It is the participatory, inclusive and most democratic method of constitution making.

One study shows that, about 17 percent of the countries of the world adopted an elected constituent assembly as the main deliberative body in the development of a new constitution (Constituent Assembly, 2020). Colombia, Ghana, Haiti, Marshall Islands, Federated States of Micronesia, Namibia, Venezuela, Nicaragua, South Africa, Uganda, Nepal have used this model for making their constitution. In 2072 B.S. for the first time in the history of Nepal, a constituent assembly was elected to write a new constitution for Nepal. 'This was a dream that came true for the people of Nepal, who would for the first time author their own constitution and give themselves sovereignty over their own nation. The first task of the 601-member Constituent Assembly of Nepal was to design the constitution-making process. Some of the basic philosophies adopted for the design of the constitution-making process were to be very different from the ones adopted for the past six constitutions. Firstly, the Constituent Assembly was to adopt a bottom-up approach to constitution making; secondly, it was to be a highly participatory and deliberative process; and, thirdly, the process was to focus on consensus and inclusion' (Shakya, 2014: 90). Thus, the Constitution of Nepal 2072 B.S. is made by this process first time in Nepal. This Constitution 
was drafted by the second constituent assembly following the failure of the first constituent assembly to produce a constitution.

\section{Referendum Model}

A referendum is an election device in which the constitution can be either accepted or repealed based on the popular vote of people. 'Referendum is the process of referring a state legislative act, a state constitutional amendment or an important public issue to the people for final approval by popular vote' (Garner, 2014: 1471). Here we are dealing about the constitutional referendum for making or changing the constitution. The constitutional referendum is a popular vote for the creation, adoption or amendment of a constitution. 'Referendum allows citizens to play a direct role in making laws' (Turner, 1996: 217) and constitution making. The Venice Commission of the Council of Europe has defined constitutional referendums as "popular votes in which the question of partially or totally revising a State's Constitution is asked' (Tierney, 2018: 11). By this method people of a specific area of the country are asked to give their views, choice, interests, decision, instructions, opinion and mandate for the constitutional issues and creating the constitution. Referendum helps to incorporate the interest of all groups of people in the constitution.

Referenda also widen the scope for public participation by giving the people a direct say in policy and constitutional issues (O'Neil, 2007: 149). In a referendum, the electorate is asked to vote on a proposed decision of constitution making. A popular referendum originally involved a vote called by the electorate, whereby representative entities were compelled to raise the status of a broadly supported measure 
to law and making constitution (Addink, 2019: 134). This model of constitution making is also considered as the more participatory model but this model is rarely used in practice. Referendum allows the public to make direct decisions about constitution itself by putting certain issues before the public and allowing them to decide. Referendum can be used either before or after drafting the constitution. The concerned authority of the state makes briefings and posted its agenda for making new constitution or present already prepared draft of the constitution for public discussion in order to finalize it for the enactment. For presenting proposal for drafting the new constitution or after preparing the draft of the constitution the concerned state authority invites for public participation of the citizens, civic groups and concerned stake holders to express and collect their comments, criticisms, substantive consultations, opinions and suggestions after presenting proposal for drafting the new constitution or to modify or finalize the prepared draft of the constitution.

Sharing the draft constitution with the people and seeking and incorporating their views are crucial for participatory constitution-making (Khanal, 2014: 6). Referendum issues usually deal with the changes in the state constitution or other items of major importance (Turner, 1996: 217). It can be adopted before constitution making process for taking the views of citizens about how to make the constitution or what kind of constitution shall be made. Likewise, it can be used after formulating draft of the constitution for taking the sentiments of citizens in the constitution making process regarding the whole subject matter of constitution or certain issues/parts of the constitution or for the amendment of the constitution. Likewise, in this model, the constitution can be 
drafted by the experts, panel committee or commission and with the draft of the constitution the concerned authority can go to referendum for taking opinion and suggestions of the citizens or for approving, conforming and finalizing the draft of the constitution.

Already towards the end of the 1980 s, more than fifty per cent of the written constitutions of the world embodied a referendum mechanism of some kind. This is not so popular model in the constitution making process. In the modern time referendum has emerged as an instrument in the founding of new constitutions and modifying the existing constitution. 'Australia is one example; in Australia, referenda are used to propose parliamentary-approved changes to the Australian Constitution' (Addink, 2019: 135). The use of referendums in processes of constitutional formation and change has increased considerably across the world in recent decades. In Nepal referendum was held in 2036 B.S. but that referendum was not held for making constitution.

\section{Draft Committee Model}

Literally, committee is an assembly or board of persons to whom some task is assigned. Constitution draft committee is a group of persons elected or appointed to perform the task of creating the constitution. It is a special group delegated to make the constitution. Constitution draft committee is the body of one or more members appointed to consider, prepare and report the constitution. It is a group of persons appointed or formed for drafting the constitution. Constitution making process is a technical task and is performed by a group of technical hands by making committees. Constitution draft committee may be under the Constituent Assembly or can also remain separately under the concerned authority of the 
state. Constitution drafting committee are of two types:

\section{i. Committee appointed by the Executive, Ruler or} Head of the State: This model is also known as executivedirected constitution making. Government or the concerned authority of the state can form a separate committee for drafting the constitution. In this model first of all initial text or draft is prepared and it is approved either by the ruling party, ruler or by the head of state or the cabinet. In some of these cases the members of the appointed drafting committee consulted leaders of civic groups and nascent political parties.

ii. Committee appointed by the Legislature: In the same manner, committees can also be formed in the constituent assembly such as thematic committees, procedural committees and constitutional committee. The committees consist of constituent assembly members as well as experts. It may also have an expert drafting committee to finalize the first draft. Drafting of constitution often occurs within thematic committees and is supported by legal experts, who then report out to the full plenary (or convening of all members of the drafting body) to review and approve the draft language and subject matter. Likewise, 'the idea of involving all of the constituent assembly members in committees was to make sure that the members were properly mobilized in the constitution-making process and to ensure that a sense of ownership in the new constitution was created. The committee system formed the basic foundation for the work of the constituent assembly and the committees conducted almost eighty percent of the work of constitution making' (Shakya, 2014: 93).

These committees are assigned the responsibility for 
creating a consolidated draft of the constitution. After preparing the draft; it would be deliberated in detail in the committees and proper recommendations would be made by the committees to the concerned authority as to the provisions to be contained in the new constitution, which would come up with a complete draft constitution. 'Constitutional committee should be created representing all of the political parties. This committee will discuss and decide on the guidelines for drafting the new constitution. The constitutional committee will have to create a subcommittee representing major political parties and interest groups for dispute resolution. It will also have to create an expert drafting committee to finalize the first draft of the constitution based on its guidelines. The expert drafting committee should be small in size (no more than ten members) and should be mix of politicians and expert from outside' (Shakya, 2014: 101). Constitutional drafting committees contribute to an informed drafting process and provide equal access to all sides of the debates to research and information. Ideally, committees should be independent and capable of considering the long-term interests of the state and society, instead of the short-term interests of political faction's eager for re-election (Benomar, 2003: 8).

Constitution drafting committee are responsible towards the concerned person or authority. This committee can form a technical advisory group under it and draft a constitution by it. Committee submitted their draft of the constitution to the concerned authority after rigorous discussion on the issues and incorporating the feedback of the people and expert opinion. The drafting committee receives various recommendations from the concerned authority of the state and it accommodates them into the draft. The 
sole responsibility of making a democratic and inclusive constitution is in the hands of a drafting committee. It arranges the reports of other various committees in the draft of a constitution and makes a constitution as a living one.

Countries like Algeria, Philippines, Qatar, Thailand and Nepal have adopted this model for making constitution. In context of Nepal, Government of Nepal Act 2004 B.S. was also drafted after the formation of committee. For the enactment of this constitution Prime Minister Padma Shamsher formed the "Bhaidanik Sudhar Samiti" in $15^{\text {th }}$ Baishak 2004 B.S. in the chairmanship of Bahadur Shamsher JBR (Janga Bahadur Rana) and other members were Singh Shamsher J.B.R., Krishna Shamsher JBR, Mrigendra Shamsher J.B.R., Brahma Shamsher J.B.R., Sharada Shamsher J.B.R., Bijay Shamsher J.B.R., Nayab Bada Guru Jyu, Heramba Raj Pandey, Bada Kaji Ratna Man Singh, Sardhar Gunja Man Singh, Sardar Narendra Mani Acharya Dixit, Subarna Shamsher J.B.R. (Member Secretary) and Kula Nath Lohani (Advisor). This committee have got the mandate to recommend members in the house of legislature, forming the local bodies and separating the judicial department from executive branch of the country (Regmi Part-I, 2061: 6).

To support this committee Prime Minister Padma Shamsher requested his counterpart Mr. Jawaharlal Nehru (Prime Minister of India) to send some constitutional experts from India. Prime Minister Nehru had sent the team lead by his trustworthy friend Mr. Prakash Gupta (Law graduate from Cambridge University who was also a member of the Indian Constituent Assembly, Ram Ugra Singh and Ragu Nath Singh (Member of Uttar Pradesh Legislative Assembly) 
Professor of Law at Lakhnow University were invited and involved to draft the first constitution of Nepal (Regmi Part-I, 2061: 7). After that the Constitution of 2015 B.S. was drafted by British constitutional expert Sir Ivor Jennings as a consultant and expert of the committee. 'The Interim constitution of Nepal 2063 B.S. was drafted by the Fifteen member's "Interim Constitution Draft Committee" under the chairmanship of Former Justice of Supreme Court of Nepal Mr. Laxman Prasad Aryal and other members were Senior Advocate Harihar Dahal, Sindhu Nath Pyakurel, Mahadev Yadav, Shambhu Thapa, Khim Lal Devkota, Agni Kharel, Pushpa Bhushal, Chhatra Kumari Gurung, Shanta Rai, Shushila Prajapati, Parashuram Jha, Chandeshor Shrestha, Kumar Yonjan Tamang and Min Bahadur Bishwakarma' (Regmi Part-I, 2061: 7).

\section{Gift Model}

Gifted constitution is the constitution which is prepared according to the intention and interest of the ruler. In this model of constitution making people are not recognized as the source of state power rather the constitution is drafted by so called experts as per the guidance, will and mandate of the ruler. There is no participation of people in the constitution making process and the constitution is not based on the contractual principles and participatory principle instead, constitution comes as a gift of the ruler. This mode of constitution making is effective when the sovereignty of people and state power is seized by the ruler or dictator in the name of the people. In such condition the ruler rule the state according to their will.

For drafting this kind of constitution the ruler hires experts of his favor who are loyal to him or the ruler solely draft 
the constitution and promulgate according to the situation. Where there is this type of constitution the ruler claims him as the ultimate source of sovereign power and the constitution. The Constitution of Nepal, 2019 B.S. is the suitable example of this constitution which was gifted by king Mahendra Shah after he seized the state power by banning the political parties. This constitution was considered as a gift of the king Mahendra to his citizens and nation because it was made according to the interest and command of the king. It is said that this constitution was also made by some experts loyal to the throne.

\section{Conclusion}

Constitution is the supreme and fundamental law of the state. It is the framework and guideline of the state and it determines the structure of the state. It is a body of rules which regulates the system of government within a state. It establishes the bodies and institutions which form part of that system, it provides for the power which they are to exercise, to determine how they are to interact and co-exist with one another and perhaps most importantly of all, it is concerned with the relationship between government and the individual. Constitution making is the process of creating, drafting, designing and constructing a new constitution for the state. Constitution making is the act of creating and reforming the body of fundamental principles that govern a state. Constitution-making includes both the process for making a new constitution or amending an existing constitution as well as the substantive decisions about the design, form and content of the new or amended constitution. Being the supreme and fundamental law of the land constitution and constitution making process is quite important for the state because it involves in the restructuring of the state and it also determines 
the future of the state.

In this study the author made findings that, every constitutionmaking process is unique. There is no exact method, formula and procedure for making constitution. Constitutional making process may differ from country to country according to nature or interest of ruler or state/government, need, geographical, social, cultural, religious, economic, historical, political and legal system of a concerned country. So, as per the above conditions, variations are generally tied to the local context or ongoing political climate for making the constitution and any of the models can be used in the making of a constitution. All constitution-making processes are different, there are some distinctive features of several models of constitution-making. The legitimacy of the constitutional making process and the constitution itself is measured by the degree to which the process is democratic, participatory, open, socially inclusive, accountable, transparent, etc.

Constitution which is made by democratic model and procedures can be citizens friendly and durable one. Therefore, the principal focus is the method whereby the constitution is made and enacted, which includes the key actors and forms of representation and the mode of enactment. While reviewing and analyzing the Nepalese constitution making history from the past to the present period, there is no uniformity in adopting the model in making the constitution. The constitution making process of Nepal in different periods has adopted different models. Till this period except referendum all the above mentioned models were already used in the constitution making of Nepal in different periods. Thus, states can use any of the models for making the constitution as per their need, economy, time, situation, convenience, etc. 


\section{References}

Acharya, B. (2010). Constitution-making and Immutable Principles, Nepal Law Review, 35 (22).

Addink, H. (2019). Good Governance Concept and Context, (1 $1^{\text {st }}$ edition). United States of America: Oxford University Press.

Benomer, J. (2003). Constitution-Making and Peace Building: Lessons Learned from the Constitution Making Process of Post-Conflict Countries, UNDP.

Britannica Ready Reference Encyclopedia (2004). Vol. 3, New Delhi: Encyclopedia Britannica (India) Pvt. Ltd. and Impulse Marketing.

Constituent Assembly (2020). available at http://pcwcr.princeton. edu/drafting/models.html, accessed on 6 January 2020.

Constitution Making Process, (2019). available at https://law. unimelb.edu.au/constitutional-transformations/research/ constitution-making, accessed on 29 August 2019.

Garner, B. A. (2014). Black's Law Dictionary, (10 ${ }^{\text {th }}$ edition). U.S.A: Thomson Reuters.

Kapur, A.C. (1957). Principles of Political Science, (5 ${ }^{\text {th }}$ edition). New Delhi: Premier Publishing Co.

Karki B. \& Edrisinha, R. (2014). Participatory Constitution Making in Nepal Issues of Process and Substance, Post Peace Agreement Constitution Making in Nepal, Vol. I, Kathmandu: UNDP Support to Participatory Constitution Building in Nepal.

Khanal, K. (2014). The Participatory Constitution Making Process in Nepal: An Assessment of the CA Process (20082012), Participatory Constitution Making in Nepal Issues of Process and Substance, Post Peace Agreement Constitution 
Making in Nepal, Vol. I, (Buddhi Karki and \& Rohan Edrisinha eds.), UNDP Support to Participatory Constitution Building in Nepal.

Koirala, B. (2006). Role of Constituent Assembly in Strengthening Democracy: A Nepalese Perspective, $A$ Dissertation of LL.M., Subitted to Tribhuvan University, Kathmandu: Central Department of Law.

O'Neil, P. H. (2007). Essentials of Comparative Politics, (2 ${ }^{\text {nd }}$ edition). New York: W.W. Norton \& Company.

Regmi, M. (2061). Constiututional Development and The Constitution of Kingdom of Nepal 2047 Part I (In Nepali), ( $1^{\text {st }}$ edition). Kathmandu: Sita Devi Regmi et. al.

Regmi, M. (2061). Constiututional Development and The Constitution of Kingdom of Nepal Part II (Nepali), Kathmandu: Sita Devi Regmi et. al.

Shakya, P. M. (2014). Review of the Past Constitution-making Process and Lessons for the Future, Participatory Constitution Making in Nepal Issues of Process and Substance, (Budhi Karki \& Rohan Edrisinha eds.). Kathmandu: United Nations Development Program.

Sharma, S.R. (2003). Encyclopedia of Constitutional Law, Vol.

1., ( $1^{\text {st }}$ edition). New Delhi: Anmol Publications Pvt. Ltd.

Shrestha, A. (2075/076). Constitutional Development and Constitutionalism in Nepal (With Historical Documents), ( $1^{\text {st }}$ edition). Kathmandu: Madhuban Prakashan.

Singh, J. P. (2064). Constitution Making Process in Nepal, $A$ Dissertation of LL.M. Submitted to Tribhuvan University, Kathmandu: Central Department of Law.

Singh, M.P. (2013). V.N. Shukla's Constitution of India, (12 ${ }^{\text {th }}$ edition). Lucknow: Eastern Book Company. 
Strong, C.F. (1975). A History of Modern Political Constitution, London: ELBS.

The Constitution of Nepal (2072). Government of Nepal, Ministry of Law, Justice and Parliamentary Affairs, Kathmandu: Law Books Management Board.

Tierney, S. (2018). Reflection on Referendums, International IDEA Discussion Paper, Sweden: International IDEA.

Timalsena, R. K.(2064). Constitution, Constitutionalism and Conscience of the Constitution, Supreme Bar Journal, Vol. 1, Kathmandu: Supreme Court Bar Association.

Turner, Mary et. al. (1996). American Government Principles and Practices, U.S.A: Merrill Publishing Company. 